\title{
obituaries
}

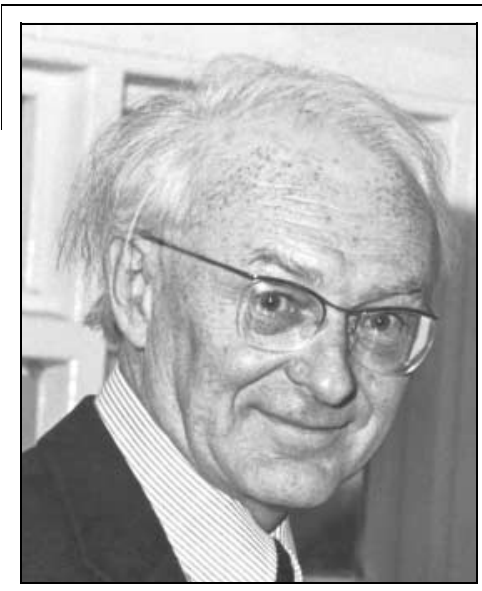

\section{Leo Max Honigsberger}

Former Consultant Clinical Neurophysiologist

Queen Elizabeth Hospital, Birmingham

There is always a lasting camaraderie among the small group of usually young clinical investigators who find themselves as pioneers in a new, clinically relevant discipline. Such was the position of clinical neurophysiology in the early 1960s when Leo Honigsberger, a trainee psychiatrist, turned from his chosen path and joined Dr Samy Last as senior registrar in the new department of clinical neurophysiology at the London Hospital in Whitechapel.

Leo's arrival is remembered as bringing the buzz of an unusually sparkling and interesting personality combined with an intense practical and intellectual interest in the applications of clinical neurophysiology across medical and surgical disciplines. This approach to his chosen subject, especially electroencephalography (EEG), was to remain throughout his professional life.

Appointed consultant clinical neurophysiologist at the Midland Centre for Neurosurgery and Neurology in 1964, and at the Queen Elizabeth Hospital Birmingham from 1972, Leo worked to develop a first-class clinical service throughout the United Birmingham Hospitals and beyond, and to the Prison Service. He trained a generation of clinical neurophysiologists and technicians, taking endless trouble as mentor to each and all. His reward was their lifelong loyalty and affection.

Leo did not publish extensively. He was essentially a collaborator and used his skills to study dysfunction of the nervous system, particularly due to metabolic or toxic encephalopathies and neuropathies. This extended into a continuing interest in intraoperative EEG monitoring of open heart surgery and the associated effects of anaesthesia, profound hypothermia and arterial hypotension, as well as monitoring during carotid artery surgery.

Leo was educated at Oundle, then chose to study medicine at his father's Alma Mater, the University of Capetown, South Africa, where he qualified MBChB in 1957. He returned to England to train in psychiatry, and gained the MRCPsych in 1972 and was elected FRCPsych in 1979; having already married Joy de Kock, a talented artist, who was to be his life companion.

Memories of Leo are inseparable from his personality, remembered as bright, delightful and friendly, but also as somewhat eccentric and on occasions even mystical. 'Leo stories' abounded throughout his career. His tastes in headgear and motor cars were all his own: a University of Capetown rowing cap to set off a bright yellow MG Midget; and a deerstalker, shortsleeved shirt and a topless, sideless jeep - in the snows are fondly remembered. His letters were written on note paper decorated with intriguing emblems (such as phrenology heads or fragments of EEG). His clinical reports could contain, in addition to an interesting novel electroclinical observation, unexpected information such as 'I've found my car, did I tell you I had lost it?'

In spite of his professed impatience with bureaucracy and administrators, Leo was active in the local district and parish councils. He was a very effective Chairman of Bromsgrove and Redditch Health Authority for 3 years. He also served in the Territorial Army.

Leo did locums in his retirement and was reporting EEGs until 2 weeks before his death.

He leaves his wife, Joy, and two daughters.

Alexander S. McNeish

\section{Sylvia Mary Reid}

Former Consultant Psychiatrist Carlton Hayes Hospital, Leicester

Sylvia Reid was born in 1914 into a psychiatric family. Her father was medical superintendent and her mother a senior medical officer of a large mental hospital in the city of Cork, her brother was medical superintendent of a mental hospital in the home counties and her sister was a consultant psychiatrist in Canada. She attended Trinity College, Dublin, where she gained BA in psychology in 1937, MBChB, BAO in 1939 and the DPM (Dublin) with honours, in

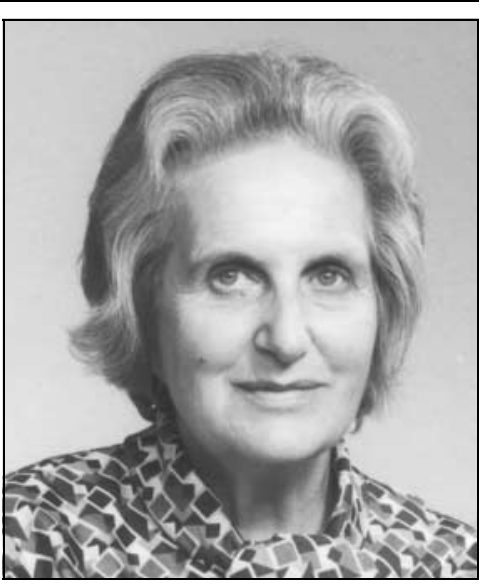

columns
1941. She was then appointed to the Royal City of Dublin Hospital, a teaching hospital, where she established one of the first psychiatric out-patient clinics in the city. After moving to the UK she steadily moved up the staffing ladder of the time, obtaining special experience in neurosis and psychotherapy, child guidance and the rehabilitation of schizophrenia, for which she set up a pioneering group of social clubs. In 1951 she was appointed Consultant Psychiatrist at Carlton Hayes Hospital in Leicester. Sylvia was of independent mind and an innovator. She disliked mental hospitals (although after her retirement she told me that she had second thoughts about her former views) and accordingly she established one of the earliest day hospitals away from a main hospital site, as a neurosis unit. Later, she set up and ran a new psychogeriatric unit along progressive lines, where she worked until her retirement.

Sylvia's psychiatric experience and her humane, insightful approach earned the respect and affection of her patients and colleagues. Her dry and quirky sense of humour, which she expressed inside and out the consulting room, made her very good company. From an early age she had to contend with a progressive and painful rheumatoid arthritis that she faced with great courage, never complaining and always taking her full share of the consultant workload of an understaffed hospital, as well as looking after her husband (also a consultant psychiatrist) and five children. In all this she was supported by her happy marriage, a devoted family and a religious faith.

She retired in 1974, having become a Fellow of the College in 1972. She was widowed in 1998. Following a sequence of strokes, she died peacefully in a nursing home on 13 June aged 87 years.

\section{Norman Kaye}

